\title{
Should a Toll-like receptor 4 (TLR-4) agonist or antagonist be designed to treat cancer? TLR-4: its expression and effects in the ten most common cancers
}

\author{
This article was published in the following Dove Press journal: \\ OncoTargets and Therapy \\ 4 November 2013 \\ Number of times this article has been viewed
}

\author{
Chun Wai Mai \\ Yew Beng Kang \\ Mallikarjuna Rao Pichika \\ Department of Pharmaceutical \\ Chemistry, School of Pharmacy, \\ International Medical University, \\ Kuala Lumpur, Malaysia
}

\begin{abstract}
Toll-like receptor 4 (TLR-4) is well known for its host innate immunity. Despite the fact that TLR-4 activation confers antitumor responses; emerging evidence suggests that TLR-4 is associated with tumor development and progression. It is now clear that overactivation of TLR-4, through various immune mediators, may cause immune response dysfunction, resulting in tumorigenesis. Different cancers could have different extents of TLR-4 involvement during tumorigenesis or tumor progression. In this review, we focus on infection- and inflammationrelated TLR-4 activation in noncancer and cancer cells, as well as on the current evidence about the role of TLR-4 in ten of the most common cancers, viz, head and neck cancer, lung cancer, gastrointestinal cancer, liver cancer, pancreatic cancer, skin cancer, breast cancer, ovarian cancer, cervical cancer, and prostate cancer.
\end{abstract}

Keywords: drug design, cancer treatment, myeloid differentiation factor 2, MD-2, tumor progression, pathogen-associated molecular patterns, PAMPs

\section{Introduction}

Toll-like receptors (TLRs) are a recently discovered family of pattern recognition receptors that show homology with the Drosophila Toll protein and the human interleukin (IL)-1 receptor family. The first member of the TLR family to be identified was a Drosophila protein ${ }^{1}$ implicated in dorsoventral patterning during embryonal development. TLRs are evolutionarily conserved proteins characterized by an extracellular leucine-rich repeat (LRR) domain, the transmembrane domain, and the cytoplasmic intracellular Toll/IL-1 receptor-like (TIR) domain. LRRs, found in both cytoplasmic and transmembrane proteins, play a vital role in ligand recognition and signal transduction. There are 12 TLRs, in which ten human isoforms of TLRs (TLR-1 to 10) have been identified. The LRR, which is deputed to recognition of the ligand, is composed of 19-25 tandem repeats of 24-29 amino acids, folded in strands and in helices that are linked by loops. ${ }^{2}$ The transmembrane domain and TIR domain are highly conserved among the TLRs. ${ }^{3}$

\section{TLR-4 structure}

Recently, TLR-4 was the first identified TLR whose crystal structure (Protein Data Bank [PDB] ID: 3FXI) was solved (Figure 1), ${ }^{4}$ leading to the derivation of computational simulation models that predict the mechanism of its interaction with its cognate ligands. The TIR domain, which shares homology with the IL-1 receptor (IL-1R), 

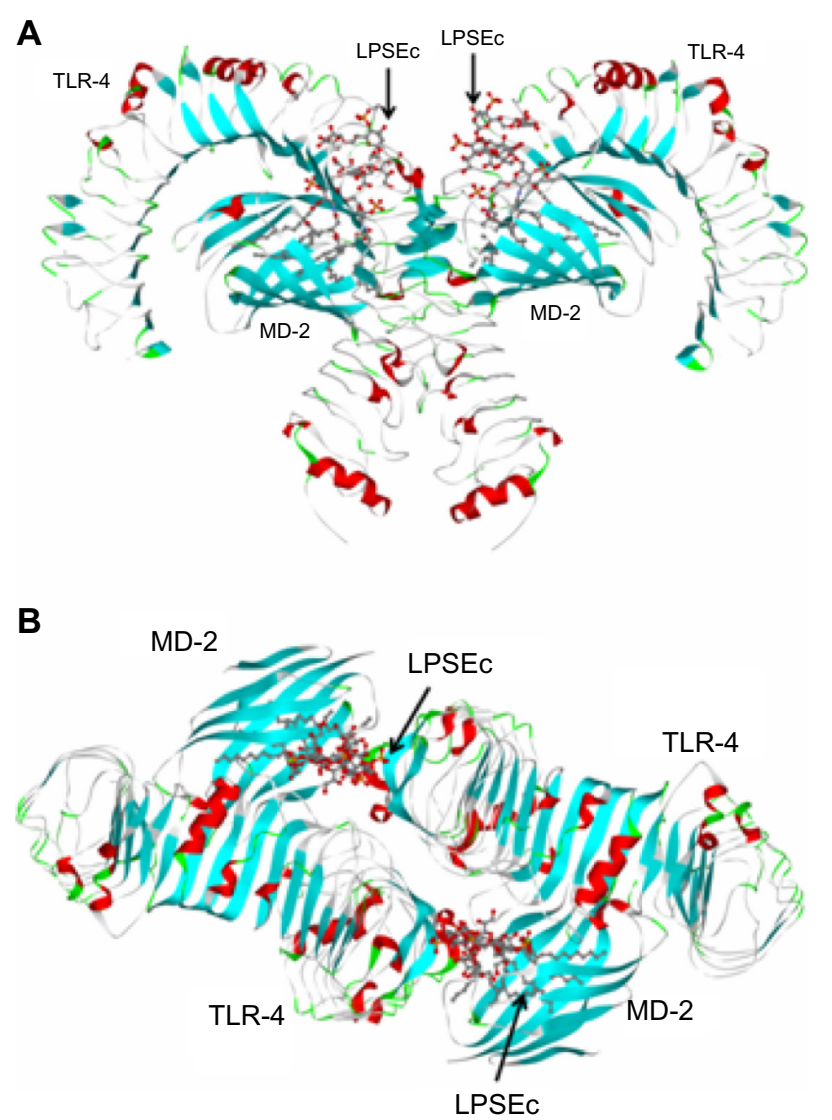

Figure I Structure of the TLR-4/MD-2/LPSEc complex.

Notes: (A) Side view of the symmetrical dimer of TLR-4/MD-2/LPSEc complex. (B) Top view of the complex. LPSEc folded in between TLR-4 and MD-2 and formed a homodimer complex. The TLR-4/MD-2 complex will initiate signal transduction that is essential for the activation of TLR-4. The images were captured in Vida 4.2.I (Open Eye Scientific Software, Santa Fe, NM, USA) software; using the human TLR-4/MD-2 crystal structure, with LPSEc cocrystalized (PDB ID: 3FXI).

Abbreviations: LPSEc, lipopolysaccharide from Escherichia coli; MD-2, myeloid differentiation protein-2; PDB, Protein Data Bank; TLR-4, Toll-like receptor 4.

is responsible for the propagation of the signal within the cell, through interaction with a complex signaling cascade. Human TLR-4 is located on chromosome 9q32-q33 and contains four exons. ${ }^{5}$

\section{TLR-4 signaling pathway}

TLR-4 regulates the inflammatory responses against gramnegative bacteria, as shown in Figure 2. Lipopolysaccharide (LPS) is the major component of the outer membrane of gram-negative bacteria and triggers TLR-4 signaling. ${ }^{6,7}$ TLR-4 requires myeloid differentiation factor 2 (MD-2) for its activation. ${ }^{8}$ LPS will first bind to the LPS-binding protein (LBP) and then to the cluster of differentiation (CD)-14 before binding to TLR-4/MD-2 complex. The role of CD-14 is to enhance the sensitivity of the TLR-4/MD-2 complex., ${ }^{910}$ The binding of LPS to the TLR-4/MD-2 complex triggers conformational changes in the structure of the TLR-4/MD-2 complex, leading to TLR-4/MD-2 homodimerization (activation) and resulting in the production of proinflammatory cytokines, through the myeloid differentiation primary response protein 88 (MyD88)-dependent pathway, and the production of type 1 interferons, through a MyD88-independent pathway (via the interaction of TIR domains with adaptor molecules). ${ }^{11}$

TLR-4 plays an important role in innate immunity as the first line of host defense. TLR-4 is expressed in normal epithelial cells, immune cells, and in cancer cells. ${ }^{12}$ Most human cells express a low level of TLR-4 and high levels of TLR-antagonist proteins, such as Toll-interacting protein (TOLLIP), which prevent the overexpression of TLR. ${ }^{13-16}$ The normal immune and epithelial cells present in the skin, digestive, respiratory, and reproductive systems activate the host's immune systems pathways through pathogen-associated molecular patterns (PAMPs) and danger associated molecular patterns (DAMPs). TLR-4 responds to the various invading exogenous pathogens through PAMPs and recognizes the endogenous ligands from necrotic cells through DAMPs (Figure 3). ${ }^{17}$ Although innate immunity appears to be a nonspecific response, it could differentiate "self" molecules and pathogens through the pattern recognition receptors on TLR-4. ${ }^{18}$

Despite the promising innate immune responses from TLR4, there is growing evidence that TLR-4 activation appears to act as a double-edged sword in cancers, ie, TLR-4 activation has been linked to both cancer inhibition and growth. Given the links of infection and inflammation with cancer, further evaluation of the role of TLR-4 in cancer is warranted. The detailed biological relationships between TLR-4 and cancers are still poorly understood. Therefore, in this review article, we gather the knowledge of TLR-4 activation in infection and inflammation related cancers. Also, we surveyed TLR-4 expression and its effects in various cancers (Table 1), viz, head and neck cancer, lung cancer, gastrointestinal cancer, liver cancer, pancreatic cancer, skin cancer, breast cancer, ovarian cancer, cervical cancer, and prostate cancer. Ultimately we wish to establish the therapeutic indication for whether TLR-4 agonist or antagonist is required in treating cancers. The details of the role of TLR-4 as one of the key mediators in innate immunity responses ${ }^{19-21}$ and of the brief relationship between TLRs and inflammatory diseases, ${ }^{22-25}$ TLR-4 and infections, ${ }^{26,27}$ and potential TLR-4 ligands ${ }^{28,29}$ are not the focus of this review paper, as these topics have been covered by other authors.

\section{TLR-4 in infection and its relation to cancer}

The recognition of PAMPs by TLR-4 during microorganism invasion occurs at the plasma membrane, endosomes, 


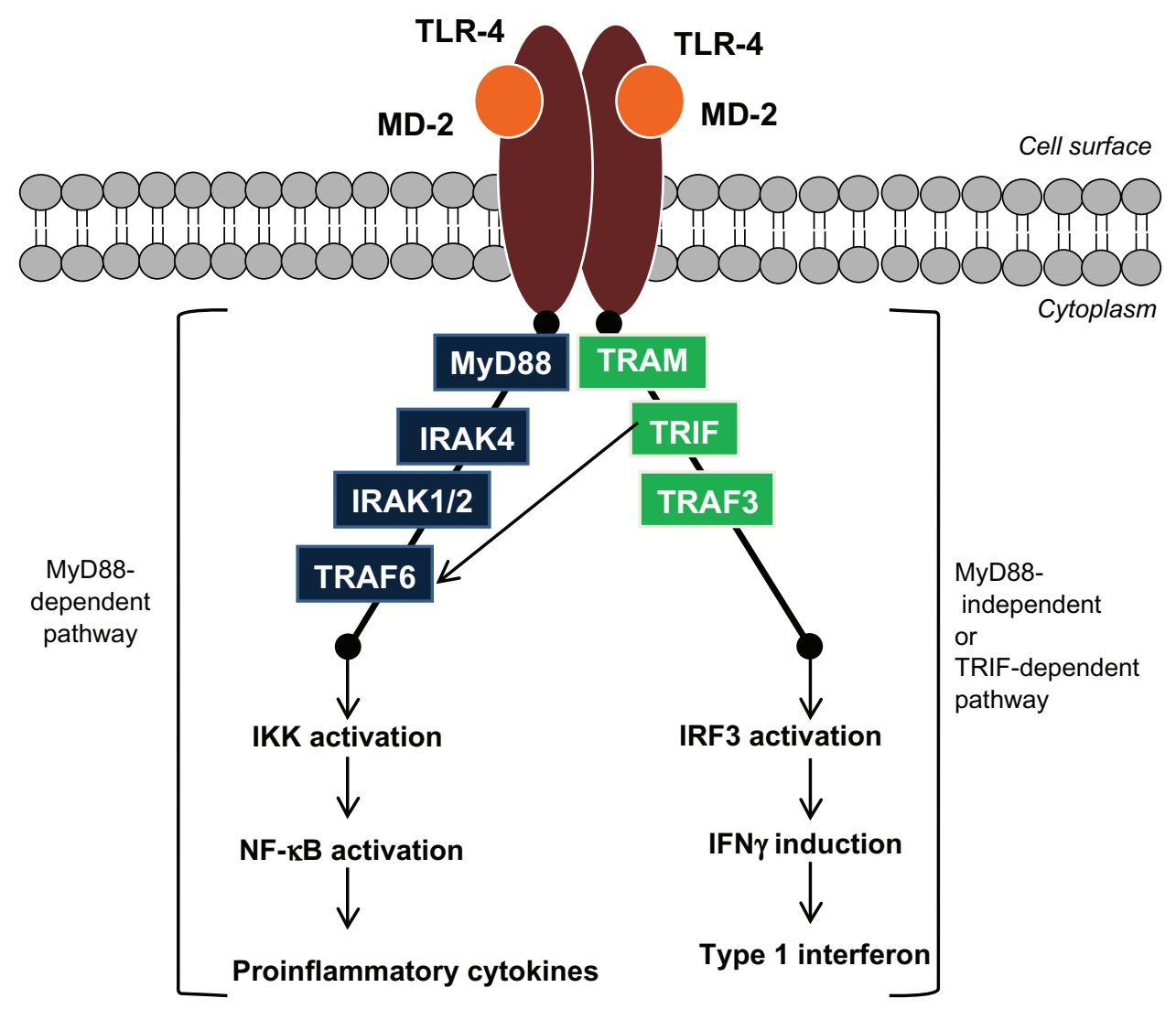

Figure 2 Schematic illustration of the TLR-4 signaling pathway.

Notes: TLR-4/MD-2 complex homodimerization activates the MyD88-dependent pathway and TRIF-dependent pathway. In the MyD88-dependent pathway, MyD88 recruits IRAK4, IRAKI/2, and TRAF6 to activate IKK and leads to NF-KB activation; in the TRIF-dependent (or MyD88-independent pathway), TRAM/TRIF activates TRAF3 and leads to IRF3 activation and induction of IFN $\gamma$.

Abbreviations: IFN, interferon; IKK, inhibitory kappa B alpha kinase; IL-IR, interleukin I receptor; IRAK, interleukin-I receptor-associated kinase; IRF3, interferon regulatory factor 3; MD-2, myeloid differentiation protein-2; MyD88, myeloid differentiation protein 88; NF-kB, nuclear factor-kappaB; TLR-4, Toll-like receptor 4; TRAF, tumor necrosis factor receptor-associated factor; TRAM, TRIF-related adapter protein; TRIF, Toll/IL-IR-domain containing adapter-inducing IFN- $\beta$.

lysosomes, and endolysosomes. ${ }^{30}$ The innate immunity usually enhances epithelial proliferation, wound healing, and the acute inflammatory responses. ${ }^{31}$ In normal host homeostasis, host immune cells activate various antitumor activities to prevent noncarcinogenic cells from evolving into carcinogenic cells. In acute pathogenic infection, $\mathrm{CD}^{+} \mathrm{T}$-cells are activated and in turn, induce natural killer cells activation. The activated $\mathrm{CD} 8^{+}$ T-cells eliminate any tumor through tumor-associated antigenspecific immunity, while the activated natural killer cells stimulate dendritic cells (DCs) to modulate adaptive antitumor immunity. However, studies have suggested that in a tumor microenvironment, the antitumor activities of the infiltrating immune cells were downregulated, due to the activated TLR-4 present in cancer cells. ${ }^{32-36}$

A recent human study reported that Helicobacter pylori, one of the common pathogenic gram-negative bacteria, induced a high expression of TLR-4 in normal gastric mucosa at the initial exposure. The authors suggested that early exposure to LPS in the gastric mucosa reduces the expression of
TOLLIP and leads to the production of proinflammatory cytokines. The overexpression of TLR-4 and the chronic production of these inflammatory cytokines contributes to aberrant transcription of caudal type homeobox 2 (CDX2), phenotypic change to intestinal metaplasia, and a lower TOLLIP expression in the cells. The progressive increase in the levels of CDX-2 activates pro-oncogenic intracellular pathways and may lead to cancer. ${ }^{16}$

An animal study supported that TLR-4-deficient mice were protected from colitis-associated tumors. ${ }^{37}$ The authors found that the MyD88 pathway of TLR-4 contributed to microbiota-induced colitis-associated cancer. The severity of chronic colitis was directly correlated with its colorectal cancer development. ${ }^{38}$ Several other studies have also suggested that MyD88 promoted carcinogenesis in epithelial cells, in several in vivo studies. ${ }^{39-41}$

Bacterial-induced inflammation via TLR-4 can also induce tumor progression. ${ }^{38}$ Killeen et al reported that LPS increases the expression of urokinase plasminogen activator 


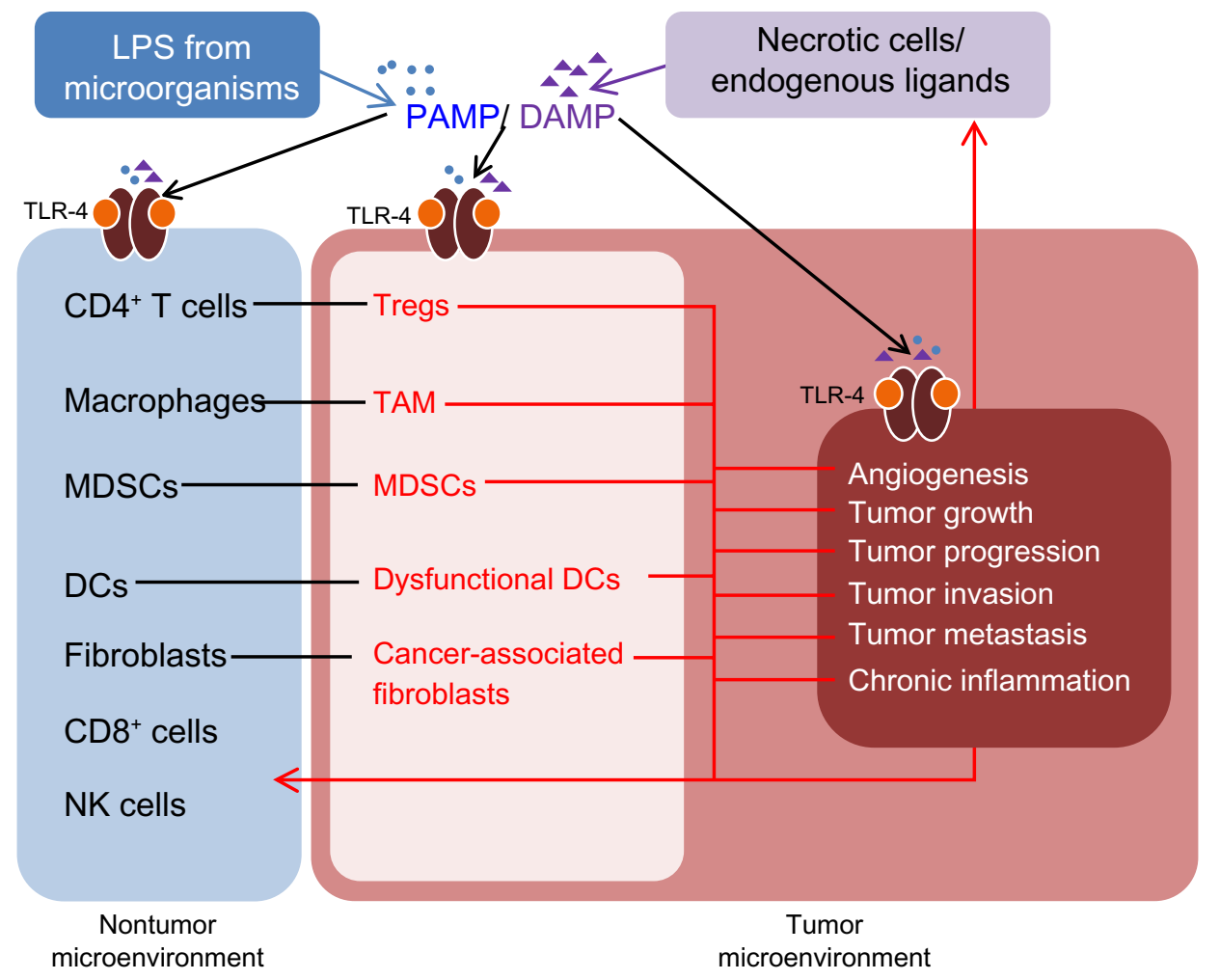

Figure 3 TLR-4 signaling induces the transformation of the nontumor microenvironment to a tumor microenvironment.

Notes: Lipopolysaccharide from Escherichia coli produces PAMP while the necrotic cells and other endogenous ligands produce DAMP. Both activate TLR-4 in both nontumor and tumor environments. Prolonged activation of TLR-4 induces CD4+ cells to be transformed into CD4 $4^{+} \mathrm{CD} 25^{+}$Foxp $3^{+}$Tregs; macrophages to be transformed into TAM; MDSCs are recruited into tumor microenvironments and activated; dendritic cells will lose antitumor effects; fibroblasts are transformed into cancer associated fibroblasts; anti-tumor effects of $\mathrm{CD}^{+}$and NK cells are impaired. In the presence of immunosuppressive cytokines, pro-inflammatory cytokines and chemokines, there is chronic inflammation, tumor growth, progression, angiogenesis, invasion, and tumor metastasis.

Abbreviations: CD, cluster of differentiation; DAMP, danger-associated molecular patterns; MDSCs, myeloid derived suppressor cells; NK, natural killer; PAMP, pathogenassociated molecular patterns; TAM, tumor associated macrophages; TLR-4, Toll-like receptor 4; Tregs, regulatory T cells; DCs, dendritic cells; LPS, lipopolysaccharide.

and urokinase plasminogen activator receptor in colorectal cancer cells. ${ }^{42}$ LPS also enhances the colorectal cancer cell adhesion and invasion, but not in the presence of TLR-4 blocking antibody. ${ }^{42}$ LPS helps the cancer cells evade immune surveillance via the production of IL-6, IL-12, inducible nitric oxide synthase as well as via the expression of antiapoptotic proteins, such as X-linked inhibitor of apoptosis. ${ }^{43,44}$ Studies have also suggested that the chronic activation of TLR-4 from microorganism invasion induces oncogenic potential in the host, through the chronic activation of nuclear factor-kappaB (NF-кB) and cyclooxygenase-2 (COX-2). ${ }^{31,45,46}$

\section{TLR-4 in inflammation and its relation to cancer}

The association between cancers and inflammation induced by PAMPs is clearly evident; however, the association between PAMPs and TLR-4 expression in cancers is minimal. This suggests nonpathogenic TLR-4-induced inflammation also plays an important role in cancers. In the noncancerous condition, cell death is usually driven by phagocytosis or apoptosis.
On the other hand, in cancer cells, necrosis-induced cell death is related to the release of DAMP (Figure 3). Certain DAMP, such as high mobility group box-1 protein (HMGB1), could potentially promote cancer progression. ${ }^{19,47}$ HMGB1 is a deoxyribonucleic acid (DNA)-binding protein secreted from cells upon cytokine stimulation or necrotic cell death. Cancer cells have been found to have high expression of HMGB1. ${ }^{48,49}$ HMGB1 has also been reported to induce cancer cell invasion, migration, and metastasis ${ }^{50,51}$ as well as in vitro endothelial cell proliferation and in vivo neovascularization. ${ }^{52}$ Anti-HMGB1 antibody was also shown to inhibit angiogenesis. $^{53}$ This evidence collectively suggests HMGB1 as an endogenous TLR-4 ligand that induces carcinogenesis. ${ }^{28,54}$ In one study, it was found that the levels of these DAMP-derived molecules were high in the tumor microenvironment and that they induced TLR-4-related chronic inflammation, leading to carcinogenesis, cancer progression, and metastasis. ${ }^{12}$ Another study highlighted that the TLR-4/MD-2 complex enhanced the formation of regions of hyperpermeability, through upregulation of $\mathrm{C}$-C chemokine receptor type 2 
Table I Summary of TLR-4 expression and its effects on various tumors

\begin{tabular}{|c|c|c|}
\hline Type of cancer & TLR-4 expression & Effect of TLR-4 \\
\hline Head and neck cancer & $\uparrow 70-72$ & $\begin{array}{l}\text { - Enhances cancer cell growth, NF-KB translocation, activated phosphatidylinositol 3-kinase/Akt } \\
\text { pathway, and upregulation of IRAK-4 expression, IL-6 production, IL-8 production, VEGF, and } \\
\text { granulocyte macrophage colony-stimulating factor }{ }^{71}\end{array}$ \\
\hline Lung cancer & $\downarrow^{75}$ & $\begin{array}{l}\text { - Inhibits lung carcinogenesis }{ }^{75} \\
\text { - Increases immunosuppressive cytokines, production of proangiogenic chemokine, and } \\
\text { resistance to apoptosis }\end{array}$ \\
\hline Esophageal cancer & $\uparrow_{35,78}$ & - Overexpression in esophageal cancers ${ }^{86}$ \\
\hline Gastric cancer & $\uparrow_{86}$ & $\begin{array}{l}\text { - Increases NF-אB signaling and IL-8 secretion }{ }^{88} \\
\text { - Increases Helicobacter pylori-induced gastric tumor cells }{ }^{90} \\
\text { - Increases further interaction with H. pylori and induces secretion of gastric carcinoma- } \\
\text { promoting factors }{ }^{90} \\
\text { - Increases COX-2 and PGE2 } 2^{33} \\
\text { - Higher risk of gastric cancer in the TLR-4 gene polymorphism }{ }^{92-100}\end{array}$ \\
\hline Colorectal cancer & $\uparrow^{87-89}$ & $\begin{array}{l}\text { - Increases COX-2 and PGE2 signaling and early colorectal carcinogenesis, inhibit apoptosis, } \\
\text { and promotes angiogenesis } 99,100 \\
\text { - Increases the generation of reactive oxygen species }{ }^{168} \\
\text { - Blocking of TLR-4 inhibits cancer proliferation } \\
\text { - Blocking of TLR-4 reverses the tumor-mediated suppression of T-cell proliferation and } \\
\text { natural killer cell activity } \\
\text { - Blocking of TLR-4 prolonged tumor-bearing mice survival }{ }^{45} \\
\text { - Increases colon cancer cell adhesion and invasion, through the urokinase plasminogen } \\
\text { activator system and } \beta 1 \text { integrin }{ }^{42,117,118} \\
\text { - Higher risk of colorectal cancer with the TLR-4 gene polymorphism }{ }^{115}\end{array}$ \\
\hline Liver cancer & $\uparrow 103,104$ & $\begin{array}{l}\text { - Increases the liver tumor formation } \\
\text { - Increases Nanog gene expression, which induces liver oncogenesis } \\
\text { - Stimulates carcinogen-induced liver injury and cancer }{ }^{12}\end{array}$ \\
\hline Pancreatic cancer & $\uparrow 123$ & $\begin{array}{l}\text { - Poor prognosis with overexpressed TLR-4 patients }{ }^{126} \\
\text { - Blocking of TLR-4 or MyD88 decreased the LPS-dependent increase of cancer invasive ability }\end{array}$ \\
\hline Skin cancer & $\uparrow 126$ & $\begin{array}{l}\text { - Increases NF-KB signaling, upregulation of MMP-2, expression, and IL-8 production }{ }^{130} \\
\text { - Increases tumor progression with persistent TLR-4 activation }{ }^{34} \\
\text { - Protects against chemical carcinogen-induced tumor formation }{ }^{133}\end{array}$ \\
\hline Breast cancer & $\uparrow^{34}$ & $\begin{array}{l}\text { - Blocking of TLR-4 inhibits cancer proliferation } \\
\text { - Blocking of TLR-4 reduces IL-6 and IL-8 } \\
\text { - Breast cancer metastasis is associated with activation of TLR-4 }{ }^{138-142}\end{array}$ \\
\hline Ovarian cancer & $\uparrow 137$ & $\begin{array}{l}\text { - Increases cytokine (IL-6, MCP-I, and CXCLI) secretion }{ }^{36} \\
\text { - Increases NF- } \mathrm{KB} \text { signaling }{ }^{36} \\
\text { - Blocking of TLR-4 improves paclitaxel resistance }{ }^{36,146,148} \\
\text { - Inducible heat shock proteins from ovarian cancer induce neutrophil activation through } \\
\text { TLR-4 and cause tumor progression as well as tumor lysis }{ }^{147}\end{array}$ \\
\hline Cervical cancer & $\uparrow_{36,146}$ & $\begin{array}{l}\text { - Pathogenic microorganisms induce upregulation of integrin } \beta 6, \text { TLR-3, and TLR-4 in cervical } \\
\text { cancer cells }{ }^{152}\end{array}$ \\
\hline Prostate cancer & $\uparrow 124,152$ & $\begin{array}{l}\text { - Increases MyD88-dependent NF-KB signaling }{ }^{158} \\
\text { - Increases VEGF }{ }^{159} \\
\text { - Increases TGF- } \beta I^{159}\end{array}$ \\
\hline
\end{tabular}

Notes: $\uparrow=$ increased compared with normal cells; $\downarrow=$ decreased compared with normal cells.

Abbreviations: Akt, protein kinase B; COX-2, cyclooxygenase-2; IL, interleukin; IRAK-4, interleukin-I receptor-associated kinase; LPS, lipopolysaccharide; MCP-I, monocyte chemoattractant protein I; MMP-2, matrix metalloproteinase-2; MyD88, myeloid differentiation protein 88; NF- $\mathrm{BB}$, nuclear factor-kappaB; PGE2, prostaglandin E2; TGF, transforming growth factor; TLR-4, Toll-like receptor 4; VEGF, vascular endothelial growth factor; CXCLI, chemokine C-X-C motif ligand I.

(CCR2) expression, in inflamed mice and thus increased the rate of lung metastasis. ${ }^{55}$ Metastasis was found to be initiated also by serum amyloid, through TLR-4-dependent NF-kB inflammation pathways. ${ }^{56}$ All these latest findings clearly suggested the pivotal role of the TLR-4/MD-2 complex in inflammation-associated cancers.

\section{TLR-4 signaling in tumor cells versus immune cells}

The hallmarks of inflammation-associated cancers are the presence of inflammatory cells and cytokines in the tumor microenvironments that leads to tumor growth, angiogenesis, tumor invasion, and/or metastasis. ${ }^{57,58}$ TLR-4 activation 
upregulates the proinflammatory cytokines and chemokines (CCL, CXCL, CCR, CXCR, IL-6, IL-18, tumor necrosis factor [TNF]- $\alpha$, etc) as well as immunosuppressive cytokine (transforming growth factor [TGF- $\beta] 1$, IL-10 etc), especially in tumor microenvironment (Figure 3). ${ }^{12} \mathrm{CD}^{+}, \mathrm{CD}^{2} 5^{+}$, and Foxp $3^{+}$regulatory $\mathrm{T}$ cells in the tumor microenvironment secrete IL-10 and TGF- $\beta$, which limit the antitumor effect of non-regulatory T-cells. ${ }^{12,59}$ In tumors, associated macrophages have been shown to release angiogenic and lymphangiogenic factors that promote metastasis. ${ }^{12,60}$ Myeloid-derived suppressor cells recruited to the tumor microenvironment under the influence of IL-1 $\beta$, IL- 6 , and prostaglandin $(\mathrm{PG}) \mathrm{E}_{2}$ were also shown to impair the antitumor response of the host, through the release of nitric oxide synthase and TGF- $\beta .{ }^{12}$ DCs too, were found to be dysfunctional in the tumor microenvironment, due to the suppressive effects of vascular endothelial growth factor (VEGF), IL-6, IL-1, TGF- $\beta$, COX-2 and PGE ${ }_{2}{ }^{12,61}$ Elsewhere, fibroblast was transformed into cancer-associated fibroblast (CAF) in the tumor microenvironment, and TGF- $\beta$-induced CAF activation promoted tumor growth and proliferation. TLR-4 activation has also been related to TGF- $\beta$ signaling-related cancer growth. ${ }^{12,62-64}$

As a result of these findings, these infiltrating immune cells were hypothesized to support cancer progression, angiogenesis, and metastasis. ${ }^{32-36}$ All the above suggest that the release of various immunosuppressive cytokines, proinflammatory cytokines, and chemokines during the activation of TLR-4 could contribute to cancer formation in normal epithelial cells, immune cells, and cancer cells.

\section{TLR-4 in modulation of angiogenesis and its relation in limiting tumor progression}

Despite the fact that activated TLR-4 has procarcinogenic effects, the antitumor effect induced by activated TLR-4 should not be neglected. One study reported that the Mycobacterium bovis bacillus Calmette-Guérin cell wall skeleton enhanced the cytotoxic activity of T-cells and macrophages against cancer cells, probably through TLR-4. Bacillus Calmette-Guérin cell wall skeleton induced TNF- $\alpha$ secretion from DCs through TLR-2 and TLR-4 signaling and thus induced the maturation of DCs. ${ }^{65}$ Elsewhere, OK-432, a penicillin-killed and lyophilized preparation of Streptococcus pyogenes exhibited potent immunotherapeutic effect in cancers. ${ }^{66}$ Studies supported that OK-PSA, the molecule isolated from a butanol extract of $\mathrm{OK}-432$, induced anticancer immunity and DC maturation, via TLR $-4 .{ }^{67}$ It was also found that OK-PSA-induced cytokine production was inhibited by anti-TLR-4 monoclonal antibody. In other work, the compound isolated from Aeginetia indica L. (AILb-A) induced $\mathrm{NF}-\kappa \mathrm{B}$ activation in NF- $\kappa \mathrm{B}-$ dependent reporter cells containing TLR-4 plasmid; AILb-A also did not induce any cytokine production in TLR-4 deficient mice ${ }^{67}$ Finally, synthetic serine-based glycolipid (CCL-34)-activated macrophages were shown to induce cancer cell death through TLR-4 dependent pathways. ${ }^{68}$ These findings suggest TLR-4 activators induce antitumor immunity through TLR-4 signaling.

\section{Role of MD-2 in cancer}

The expression of MD-2 in most cancer cells has not been well studied. Limited evidence has concluded that MD-2 plays a role in cancer progression only. One study highlighted that MD-2 was overexpressed in highly invasive colorectal cancer cells (SW837), in poorly differentiated, moderately invasive colorectal cancer cells (HT-29), and in well-differentiated but non-invasive colorectal cancer cells (Caco-2). ${ }^{69}$ Another study reported that serum amyloid A 3, a major component of acute phase inflammation, binds to MD-2 and activates the MyD88-dependent TLR-4/MD-2 pathway and thus facilitates lung metastasis. ${ }^{70}$ Therefore, MD- 2 could be related to the degree of differentiation, proliferation, and migration capacity of cancers.

\section{TLR-4 in head and neck cancer}

The laryngeal carcinomas predominate in this category. ${ }^{71}$ The treatment of head and neck cancers remains a big challenge for oncologists. A study in Poland of 20 laryngeal cancer patients with no distant metastasis $\left(\mathrm{M}_{0}=100 \%\right)$ reported TLR-2-, TLR-3-, and TLR-4-expression in the laryngeal carcinoma microenvironment. Although TLR-4 is the least frequently expressed TLR on laryngeal tumors, it is still the most frequently expressed TLR on inflammatory cells in all tumor masses and tumor stroma. This fact suggests the possibility of TLR-4 involvement in the escape of tumors from immune surveillance. The detection of TLR-2, TLR-3, TLR-4, and major histocompatibility complex (MHC) class II antigens in all laryngeal carcinoma suggests the role of TLRs in the activation of adaptive immunity. ${ }^{72}$

TLR-4 was also detected in laryngeal tumor tissue $(n=27)$, oral cavity tumor tissue $(\mathrm{n}=10)$, and cancer cells (PCI-1, PCI13, and PCI-30). ${ }^{73}$ Moreover, TLR-4 levels in tumors were correlated with tumor differentiation. TLR-4 was shown to enhance the release of tumor progression mediators, resulting in tumor proliferation and progression. ${ }^{73,74}$ A study reported cancer cells express significantly higher levels of TLR-4 and 
NF- $\kappa \mathrm{B}$ compared with noncancerous cells. A positive correlation was also established between TLR-4 levels in laryngeal tumor central cells, with tumor front grading. ${ }^{74}$ Another study, published in 2012, suggested the increased activity of TLR-4, TNF receptor-associated factor (TRAF) 6, and IL-1 receptorassociated kinase (IRAK) 1 in advanced laryngeal carcinoma, suggesting the TLR-4/MyD88-dependent signaling pathway involvement in laryngeal carcinoma progression. ${ }^{75}$

\section{TLR-4 in lung cancer}

Worldwide, lung cancer is the most common cause of cancer-related deaths in men and women. Lung cancer mortality rates have been rising in recent decades. Chronic inflammatory disease, such as chronic obstructive pulmonary disease (COPD), has been identified as a risk factor for lung cancer. ${ }^{76}$ Since TLR-4 is also actively involved in the immune response against cancers, researchers have postulated that TLR-4 exerts both a defensive role in normal cells and a negative role in cancer cells. However, the available evidence is still not conclusive on the link between TLR-4 and lung cancer.

A study of functional TLR-4 and mutated TLR-4 in mice found that mice with the former had less lung capillary permeability, less weight loss, leukocyte inflammation, and primary tumor formation. Thus, the authors, Bauer et al, postulated that TLR-4 inhibits lung carcinogenesis by inhibiting tumor progression. ${ }^{77}$ The researchers proved TLR-4 activation could protect the lungs from being inflamed during any potential tumorigenesis. ${ }^{78}$ Elsewhere, a lower level of TLR-4 in the nasal epithelium of a smoker compared with a nonsmoker was observed, with a profound reduction in patients with severe COPD. ${ }^{79}$ This finding suggests the potential role of TLR-4 for airway inflammation and lung cancer progression.

In vitro studies have also found that TLR-4 is constantly expressed and upregulated on human lung cancer cells. ${ }^{33,80}$ In one study, the level of TLR-4 was significantly linked with the production of immunosuppressive cytokines, production of proangiogenic chemokine, and with resistance to apoptosis by lung cancer cells. ${ }^{33}$ Despite the reported significance of TLR-9 in lung cancer progression, ${ }^{81-84}$ a positive correlation $(P<0.05)$ of TLR-4, but not TLR-9, with tumor differentiation in lung cancer patients was reported. ${ }^{80}$

\section{TLR-4 in gastrointestinal cancer}

The gastrointestinal tract (esophagus, stomach, and small and large intestine) is often exposed to pathogens and carcinogens. Epidemiological studies suggest chronic inflammation, whether pathogen-related or not, increases the risk of gastrointestinal cancer. ${ }^{31,85}$

Globally, there has been an increase in esophageal cancer. ${ }^{86}$ Esophageal cancer usually occurs in Barrett's esophagus. The link or relationship between inflammation and tumorigenesis in esophageal cancer remains controversial. Esophageal motility allows pathogen transit from the oral cavity to the stomach, making it difficult to quantify PAMP and bacteria exposure. Single nucleotide polymorphism arrays have suggested that in patients with esophageal squamous cell carcinoma, genetic alterations in TLR-4 (9q32-q33) along with other chromosomal mutations are associated with higher cancer proliferation and metastasis. ${ }^{87}$ Immunohistochemistry and reverse transcription polymerase chain reaction of samples from 87 esophageal cancer patients revealed that TLR-4 as well as TLR-3, TLR-7, and TLR-9 are overexpressed in esophageal cancer. The isolated mononuclear inflammatory cells associated with higher lymph node metastasis and invasion were also shown to express a high level of TLR- $4{ }^{88}$ The level of mucosal expression of TLRs in the esophagus has not yet been elucidated. ${ }^{31}$

$H$. pylori infection has been identified as the root cause of stomach cancer. Gastric inflammation is an invariable finding in patients infected with $H$. pylori and represents the host immune response to the organism. H. pylori infection leads to gastric inflammation, characterized histologically by surface epithelial degeneration and infiltration of the gastric mucosa, through acute and chronic inflammatory cells. In H. pylori infections, TLR-4 on the gastric epithelial cells regulates the LPS response. ${ }^{89-91}$ Gastric biopsy samples have suggested $H$. pylori infections accelerate TLR-4 and MD-2 expression in human gastric epithelial cells, ${ }^{90}$ which in turn enables the gastric carcinoma cells to further interact with H. pylori and consequently, induce the secretion of gastric carcinoma promoting factors. ${ }^{92}$ Elsewhere, anti-TLR-4 antibody inhibited $H$. pylori-induced messenger ribonucleic acid (mRNA) expression of human $\beta$-defensin in gastric cancer cells (MKN 45). ${ }^{93}$ These results further strengthened the hypothesis that $H$. pylori induce the expression of TLR-4 in gastric epithelial cells.

Based on the report of TLR-4 signaling in colonic COX-2 expression and $\mathrm{PGE}_{2}$ production, Fukata et al suggested that there is a high correlation between TLR-4 signaling and the expression of COX-2 as well as $\mathrm{PGE}_{2}$ in H. pylori-associated gastric cancers. ${ }^{94}$ The expression of $\mathrm{NF}-\kappa \mathrm{B}$ in association with COX-2 and TNF- $\alpha$ was postulated to be mediated through TLR-4, but not through TLR-2 or -9 , based on the findings from previous research, in which 
guinea pig gastric epithelial cells were preincubated with H. pylori LPS $^{89}$

Patients with poorly differentiated gastric adenocarcinomas have been shown to have Thr35 Ala polymorphism in the LRR of TLR-4, but not TLR-2, TLR-6, or TLR-9.95 This finding supports the hypothesis that TLR-4 gene polymorphism is related to poorly-differentiated gastric adenocarcinoma. In addition, a significantly higher risk of gastric carcinoma has been found with TLR-4 Ala896Gly polymorphism. ${ }^{96} \mathrm{~A}$ case-control study of 171 Italian gastric cancer patients and 151 controls reported TLR-4 Thr399Ile polymorphism, but not TLR-4 Asp299Gly polymorphism, is linked with increased risk of gastric cancer $(P=0.023$, hazard ratio $[\mathrm{HR}]=3.62)$. Further, an increased risk of intestinal gastric cancer $(P=0.006, \mathrm{HR}=5.38)$, but not diffuse gastric cancer $(P=0.612, \mathrm{HR}=1.85)$ was reported in carriers of TLR-4 Thr399Ile allele. ${ }^{97}$ Similar results were reported by repeated studies on the role of TLR-4 Asp299Gly/Thr399Ile single nucleotide polymorphism in relation to gastric carcinogenesis. ${ }^{98,99}$ However, another case-control study carried out in Mexico reported neither TLR-4 Asp299Gly polymorphism $(P=0.82)$ nor TLR-4 Thr399Ile polymorphism $(P=0.2)$ was associated with significant incidence of gastric cancer. ${ }^{100}$

TLR-4 in colorectal cancer can be a double-edged sword, enhancing the host anticancer immunity and promoting tumor growth at the same time. In acute intestinal mucosa injury, in response to LPS, TLR-4 expression induces COX-2 expression, which leads to wound healing. Thus, mice that lack MyD88 or TLR-4 signaling have been shown to have a reduced healing ability after an acute injury. However, in chronic intestinal inflammation, TLR-4 induces COX-2 and $\mathrm{PGE}_{2}$ production, which may result in early colorectal carcinogenesis, inhibition of apoptosis, and increase of angiogenesis. ${ }^{94,101}$ Thus, blocking of TLR-4 signaling can prevent colon cancer cell (MC26 cells) proliferation and reverse tumor-mediated suppression of T-cell proliferation. Just as in other cancers, chronic inflammation in intestinal epithelial cells is closely related to the incidence rate of colorectal cancer. Healthy intestinal epithelial cells constitutively express TLR-3 and TLR-5, where TLR-2 and TLR-4 are lower in quantity. ${ }^{102}$ However, altered expression of TLRs is observed in chronically inflamed intestinal epithelial cells. ${ }^{101-103}$ TLR-4 expression is significantly upregulated in inflammatory bowel disease (IBD), but expression of TLR-2 and TLR-5 remains unchanged. ${ }^{102} \mathrm{~A}$ significant induction of TLR-2 and TLR-4 expression has been observed on the submucosa of inflamed intestinal epithelial cells. ${ }^{104}$ Also, a significant increase in TLR-4 expression was identified in the colon cancer cells. ${ }^{105,106}$ Patients with higher levels of TLR-4 in colon tumor stroma were shown to have an earlier relapse (14 months) compared with those who had lower expression (40 months). ${ }^{105}$ This clearly suggests the role of TLR-4 in colorectal tumorigenesis and progression.

Patients suffering with IBD do have increased risk of cancer $\left(0.5 \%-1 \%\right.$ yearly). ${ }^{31}$ The impact of TLR-4 polymorphism on IBD is controversial. No association was reported with TLR-4 Asp299Gly and Thr399Ile polymorphism, in a group of IBD patients from Southern Italy, ${ }^{107}$ New Zealand, ${ }^{108}$ Germany, and Hungary. ${ }^{109}$ However, some studies have suggested a significant link between TLR-4 Asp299Gly polymorphism and either ulcerative colitis or Crohn's disease or both. ${ }^{110-115}$ In addition, a meta-analysis reported in 2010, showed a significant association between TLR-4 (Asp299Gly and Thr399Ile) polymorphism with ulcerative colitis (odds ratio $[\mathrm{OR}]=1.08,95 \%$ confidence interval [CI]: 1.08-1.51), Crohn's disease (OR: 1.29, 95\% CI: 1.08-1.54), and IBD (OR: 1.25, 95\% CI: $1.06-1.48) .{ }^{116}$ As well, TLR-4 Asp299Gly polymorphism was significantly higher in colorectal patients compared with normal healthy adults $(P=0.0269) .{ }^{117}$ Also, studies report that LPS enhanced colorectal cancer cell adhesion and invasion, through TLR4- and NF-KB-dependent activation of the urokinase plasminogen activator system and beta-1 integrin, which ultimately leads to tumor progression. ${ }^{64,118,119}$ In vivo data suggests TLR-4 inhibition has prolonged the survival rate of tumorbearing mice $(\mathrm{BALB} / \mathrm{c}){ }^{43}$ Stimulation of the TLR-4/MD-2 complex by LPS can activate phosphoinositide-3-kinase (PI3 K) signaling and thus promotes the adhesiveness and metastatic capacity of colorectal cancer cells. ${ }^{120}$ All these findings have consolidated the role of TLR-4 in colorectal cancer progression.

\section{TLR-4 in liver cancer}

Dysregulated innate immunity is an integral component in liver disease. Chronic liver diseases, such as alcoholic liver cirrhosis, have also been established as the major cause of liver cancer. ${ }^{121}$ Many liver cells (Kupffer cells, hepatocytes, stellate cells, biliary epithelium, and sinusoidal endothelium) constantly express TLR-4. ${ }^{122}$ The levels of TLR-4 have been found to be upregulated in hepatitis $\mathrm{B}$ - and hepatitis $\mathrm{C}$-infected cells $\mathrm{s}^{123,124}$ and further upregulated in alcohol-induced liver damage and tumors. ${ }^{125,126}$ On the other hand, diethylnitrosamine, a carcinogen, was shown to stimulate TLR-4 signaling in mice, resulting in an increase in the size and number of tumors, while the size 
and number of tumors were found be reduced in MyD88 deficient mice. ${ }^{40}$

\section{TLR-4 in pancreatic cancer}

It is very difficult to detect pancreatic ductal adenocarcinoma at early stage because of its anatomic location and insidious nature. LPS could be a triggering factor in the initiation and progression of pancreatitis and pancreatic cancer., ${ }^{7,127}$ This suggests the possible role of TLR-4 in pancreatic cancer since LPS is a well-established agonist of TLR-4.

Significant expression of TLR-4 $(P=0.002)$ was detected in a study of pancreatic ductal adenocarcinoma as compared with adjacent normal tissues. ${ }^{128}$ In this study, there was no correlation found between the levels of TLR-4 and age, gender, location and differentiation of tumor; however, TLR-4 levels were correlated with tumor size, lymph node involvement, venous invasion, and pathological stage. Positive correlations were also observed between TLR-4 and hypoxia-inducible transcription factor- $1 \alpha(\mathrm{HIF}-1 \alpha)$. The expression of NF- $\kappa \mathrm{B}$ phosphorylated $\mathrm{p} 65$ was also higher in the tumor cells. The patients with overexpressed TLR-4 or overexpressed HIF-1 $\alpha$ had a significantly shorter survival period than did the patients with normal expression $(P=0.011$ and $P=0.005$, respectively). Longer survival $(P=0.014)$ was noted among patients with neither TLR-4 nor HIF-1 $\alpha$ overexpressed compared with patients who had both TLR-4 and HIF- $1 \alpha$ overexpressed. ${ }^{130} \mathrm{~A}$ separate in vitro study on human pancreatic cancer cells (Panc-1 and AsPC-1) revealed that TLR-4 was responsible for the invasive ability of cancer cells, mostly due to TLR-4-dependent NF- $\kappa \mathrm{B}$ activation. ${ }^{6}$ These results demonstrated the importance of TLR-4 in pancreatic cancer proliferation.

\section{TLR-4 in skin cancer}

Not only is skin the largest organ in our human body, it also protects us from pathogen invasion through its innate and adaptive immunity. A study has drawn attention to the role of TLRs in atopic dermatitis, psoriasis, acne vulgaris, and skin infection and has suggested the potential of TLRs as a therapeutic target to treat skin cancer. ${ }^{129}$ Melanoma cells have a significantly higher amount of TLR-4 levels. ${ }^{130-133}$ An in vitro analysis showed the consistent expression of TLR-4 on 13 out of 15 established human metastatic melanoma cells (ME1, ME2, ME5, ME7, ME8, ME9, ME16, ME17, ME18, ME19, ME20, ME21, and ME22) tested. The expression of TLR-2 and -3 was also detected in some, but not in all. TLR-1,-5,-6,-7,-8,-9, and -10 were either absent or weakly expressed. The TLRs, including TLR-4, were upregulated in melanoma, ${ }^{32}$ and it was noted that the coadministration of paclitaxel and icariside II (isolated from Herba Epimedii) enhanced apoptosis and decreased the levels of IL-8 and VEGF in human melanoma A375 cells, through the inhibition of TLR-4/MyD88 signaling. ${ }^{134}$ A group of German scientists found that TLR-4 was involved in melanoma responses to hyaluronic acid-induced tumor invasion and metastasis. ${ }^{132}$

Another study suggested that the chemical carcinogen 7,12-dimenthylbenz(a)anthracene (DMBA) is associated with endotoxin hypersensitivity mediated through TLR-4-triggered T-cell activation, resulting in cell-mediated immunity. In that study, TLR-4-deficient mice were found to have more tumors compared with normal mice. ${ }^{135}$ Another study showed that melanoma inhibits macrophage activation by suppressing TLR-4 signaling. ${ }^{136}$ An interesting theory, proposed by Sanchez-Perez et al, is that the intentional generation of an autoimmune response by normal cells could generate a potential antitumor response against tumors of the same type cells. This would explain their finding that the heat shock protein (Hsp)70, a potent immune adjuvant acting through TLR-4 activation, kills inflammatory melanocytes. ${ }^{131}$ Thus, TLR-4 activation could be beneficial, at the initial stage, to control melanoma progression. However, the persistent activation of TLR-4 may be harmful to the host.

\section{TLR-4 in breast cancer}

Breast cancer is one of the most common cancers affecting women worldwide. The current available therapy has yet to meet the desired outcomes. Two research teams have suggested the role of TLR-2 $2^{137}$ and TLR-9 ${ }^{138}$ in breast cancer proliferation. In 2010, Yang et al reported that ten TLRs were expressed in MDA-MB-231 cells, the estrogen receptor-negative human breast cancer cells. Among all the TLRs, TLR-4 expression was the highest and was five times higher than TLR-3 expression (the least expressed among the remaining TLR-1 to TLR-10). Functional analyses of ribonucleic acid interference (RNAi) against TLR-4 revealed this successfully inhibited the growth and proliferation of MDA-MB-231 cells and resulted in a significant $(P<0.05)$ reduction of inflammatory cytokines. ${ }^{139}$

In other work, 4T1 (spontaneously metastasizing mammary adenocarcinoma) cells challenged with lipopolysaccharide induced tumor growth and metastasis, by increasing angiogenesis, vascular permeability, and tumor invasion. ${ }^{140,141}$ An immunohistochemical study on clinical carcinomas showed a significant association of high TLR-4 expression with local cancer proliferation and lymph node metastasis. ${ }^{142}$ 
A total of 74 breast carcinomas were collected from patients to study the clinical relevance of TLRs in breast cancer. Tumors with high TLR-4 expression, but not TLR-9 expression, in mononuclear cells were found to have a higher probability of metastasis. ${ }^{143}$ In metastatic breast cancer cells, activated TLR-4 regulates the expression of mediators that promote cancer adhesion and invasion. In addition to this, TLR-4 signaling increases microRNA 21 (miR-21) in breast

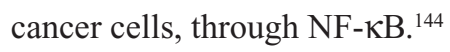

Incidents of relapses have been shown to be high in breast cancer patients harboring the TLR-4 Asp299Gly polymorphism who were treated with anthracycline-based chemotherapeutic drugs. ${ }^{145}$ This polymorphism also confers to an increased risk of breast cancer progression. ${ }^{146}$ However, the levels of the TLR-4 Ala896Gly allele in breast cancer patients were not found to be significantly different from those levels in normal healthy Caucasian women. ${ }^{147}$ These studies suggest TLR-4 involvement in breast cancer progression. Future studies are warranted, in developing novel therapeutic approaches targeting TLR-4 against breast cancer.

\section{TLR-4 in ovarian cancer}

A proinflammatory environment in the ovary, such as with ovarian endometriosis, predisposes women to ovarian cancer. Epithelial ovarian cancer cells have been found to express TLR-4, but not the adjacent nondysplasia cells. ${ }^{34,148}$ It has been found that ovarian tumors derived from the surface epithelium of normal ovaries express TLR-4, which leads to NF- $\kappa \mathrm{B}$ inhibitor (IkB) degradation and the activation of NF- $\kappa \mathrm{B}$ for its proinflammatory responses. The MyD88 pathway, a downstream signal of TLR-4, is reported to be essential for LPS-induced ovarian tumor growth. ${ }^{34}$ The tumor growth and survival could be due to the interaction between the inducible HspA1 A from ovarian cancer cells with TLR-4 expressed on the neutrophil surface. These neutrophils enhance the production of reactive oxygen species and induce tumor progression as well as tumor lysis. ${ }^{149}$

Paclitaxel has been the drug of choice for the treatment of ovarian cancer. A recent study has proven the association of MyD88 expression with paclitaxel resistance, and paclitaxel-induced proinflammatory cytokine release. ${ }^{34}$ Paclitaxel resistance is probably due to the activation of the protein kinase B (Akt) survival pathways and the expression of the antiapoptotic protein X-linked inhibitor of apoptosis protein (XIAP) following TLR-4 ligation. ${ }^{34,150}$ The tumors have been found to be resistant to paclitaxel, a TLR-4 ligand, but not to carboplatin. ${ }^{34}$ Another laboratory finding has suggested that five ovarian cancer (OVCAR3,
SKOV3, AD10, A2780, CP70) cells with TLR-4 ligation induced IL-1 receptor-associated kinase (IRAK)-4 activation, c-Jun phosphorylation, NF- $\kappa \mathrm{B}$ activation, and IL-8, IL-6, VEGF, and monocyte chemotactic protein-1 (MCP)-1 production, all of which promote tumor survival and chemoresistance. ${ }^{148}$ These findings suggest that further research on the role of TLR-4 in relation to management and chemotherapy for ovarian cancer should be carried out.

\section{TLR-4 in cervical cancer}

The female reproductive tract is constantly exposed to pathogens and carcinogens. Cervical cancer is one of the most common cancers closely linked to infection and inflammation. Human papillomavirus (HPV) has been identified as the leading cause of cervical cancer. HPV cervical infection results in cervical morphological lesions ranging from normal to invasive cancer. ${ }^{151}$ The presence of other infectious agents, such as bacteria, protozoa, and viruses, in the female genital tract induce the inflammation and cancer. ${ }^{152} \mathrm{~A}$ multi-center case-control study revealed that Chlamydia trachomatis infection induced the cervical cancer. ${ }^{153}$ Also, pathogenic Escherichia coli and Pseudomonas aeruginosa infection, but not the nonpathogenic Lactobacillus reuteri infection, caused the upregulation of TLR-4 in cervical cancer cells. ${ }^{154}$ In human cervical cancer (HeLa) cells, TLR-4 was found to be the highest expressed TLR, more than 100 times higher compared with the other TLRs. ${ }^{126}$ This observation provides proof of the linkage between TLR-4 and the progression of cervical cancer.

Unlike other studies linking higher levels of TLR-4 with cancer, it was found that TLR-4 is downregulated in cervical intraepithelial neoplasia patients compared with healthy women. TLR-4 expression was found to decrease as the histopathologic grade of cervical intraepithelial neoplasia increased. TLR-4 expression was found to be inversely proportional $(P<0.001)$ with the expression of $\mathrm{p} 16 \mathrm{INK} 4 \mathrm{~A}$, a marker of high-risk HPV infection. ${ }^{155,156}$ There are limited studies that conclude on the role of TLR-4 in cervical cancer progression; thus, the TLR-4 Thr399Ile polymorphism $(P=0.044, \mathrm{OR}=2.51,95 \% \mathrm{CI}: 1.03-6.12)$ was, again, found to be significantly associated with early stages of cervical cancers among North Indian women. ${ }^{157}$ Therefore, further research is needed to fully understand the role of TLR-4 in cervical cancer.

\section{TLR-4 in prostate cancer}

Prostate cancer is one of the most common causes of morbidity and mortality in men. Prostate epithelial cells are 
actively involved in inflammatory processes. ${ }^{158}$ Higher levels of proinflammatory cytokines, produced through TLR-3, -4, and -9 downstream signaling pathways, were observed in the prostate tissues of cancer patients. In this study, TLR-3 -4 and -9 were highly expressed in prostate cancer tissues but not in benign tissues. Only TLR-3 levels, and not TLR-4 or TLR-9 levels, were found to have statistical significance ( $P=0.016)$ with levels of preoperative serum prostate-specific antigen, in prostate cancer patients. ${ }^{159}$

However, in vitro studies have shown the expression of higher levels of TLR-4 on human prostate adenocarcinoma (DU-145) cells and its activation, leading to NF- $\kappa B$ and proinflammatory cytokine production through the MyD88dependent pathway. ${ }^{160}$ Also, TLR-4 activation was found to increase the proangiogenic factor (VEGF) and immunosuppressive cytokine (TGF- $\beta 1$ ) secretion in human prostate adenocarcinoma (PC3) cells. ${ }^{161}$ Further, a knockdown of TLR-4 in PC3 cells resulted in the reduction of tumor cell migration and invasion. ${ }^{162}$ These results support the negative impact of TLR-4 upregulation in prostate cancer.

In addition, single nucleotide polymorphism in the TLR-4 gene is suspected to be associated with the risk of prostate carcinoma. ${ }^{163}$ The sequence variant $(11381 \mathrm{G} / \mathrm{C}$, also known as rs11536889) in the $3^{\prime}$-untranslated region of the TLR-4 gene was found to be higher in patients with prostate carcinoma, in studies conducted on 1,383 Swedish patients ${ }^{164}$ and 157 Korean patients. ${ }^{165}$ In one study, a significantly higher risk of prostate cancer (OR: 1.26; 95\% CI: 1.01-1.57) was detected among men who had a single nucleotide polymorphism of TLR-4 (GC or CC) compared with the wild-type genotype (GG). ${ }^{164}$ However, other studies found no association of prostate cancer (OR: 1.01; 95\% CI: 0.79-1.29) with this rs11536889 sequence variant of TLR-4; ${ }^{166,167}$ one of these, a study involving 700 prostate cancer patients found that homozygosity of the variant alleles of these eight single-nucleotide polymorphisms of TLR-4 including rs2149356 were found to have a lower risk of prostate cancer. ${ }^{166}$ A case-control study of 506 incident advanced prostate cancer patients found two single nucleotide polymorphisms of TLR-4 (rs10759932 and rs2149356) were associated with a higher cancer risk. ${ }^{167}$ Nevertheless, Lindstrom et al have suggested that the association of TLR-4 with prostate cancer risk is a chance finding and that to ascertain the relationship, large sample sizes are needed. ${ }^{168}$ The inconsistent findings of the association of genetic polymorphism of TLRs with cancer progression clearly supports the need for further investigation in this field.

\section{Conclusion}

The activation of TLR-4 is required for host defense against gram-negative bacteria. However, TLR-4 activation may be a double-edged sword, with both antitumor and protumor responses. The general expression of TLR-4 by all the tumor cells, suggesting TLR-4 signaling, may be continually activated and contribute to tumor initiation, progression, and also invasion. Tumor progression involves TLR-4-mediated irregular and uninhibited production of proinflammatory cytokines, chemokines, and also immunosuppressive cytokines; suggesting that the discovery of TLR-4 antagonists might be an ideal strategy to treat cancer. However, TLR-4 antagonists could pose the risk of the compromise of host immunity. Hence, it is a scientific dilemma whether a TLR-4 agonist or antagonist should be targeted for the treatment of cancer. Further studies need to be carried out to fully elucidate the effects of TLR-4 agonists and antagonists in various cancers.

\section{Acknowledgments}

Authors wish to thank International Medical University for financial support (IMU 226/2010).

\section{Disclosure}

The authors report no conflicts of interest in this work.

\section{References}

1. Medzhitov R, Preston-Hurlburt P, Janeway CA. A human homologue of the Drosophila Toll protein signals activation of adaptive immunity. Nature. 1997;388(6640):394-397.

2. Jin MS, Lee JO. Structures of the toll-like receptor family and its ligand complexes. Immunity. 2008;29(2):182-191.

3. O'Neill LA, Bowie AG. The family of five: TIR-domain-containing adaptors in Toll-like receptor signalling. Nat Rev Immunol. 2007;7(5): 353-364.

4. Park BS, Song DH, Kim HM, Choi BS, Lee H, Lee JO. The structural basis of lipopolysaccharide recognition by the TLR4-MD-2 complex. Nature. 2009;458(7242):1191-1195.

5. Opal SM, Esmon CT. Bench-to-bedside review: functional relationships between coagulation and the innate immune response and their respective roles in the pathogenesis of sepsis. Crit Care. 2003;7(1): 23-38.

6. Ikebe M, Kitaura Y, Nakamura M, et al. Lipopolysaccharide (LPS) increases the invasive ability of pancreatic cancer cells through the TLR4/ MyD88 signaling pathway. J Surg Oncol. 2009;100(8):725-731.

7. Del Pozo JL. Primers on molecular pathways: lipopolysaccharide signaling - potential role in pancreatitis and pancreatic cancer. Pancreatology. 2010;10(2-3):114-118.

8. Nagai Y, Akashi S, Nagafuku M, et al. Essential role of MD-2 in LPS responsiveness and TLR4 distribution. Nat Immunol. 2002;3(7): 667-672.

9. Gioannini TL, Teghanemt A, Zhang D, et al. Isolation of an endotoxinMD-2 complex that produces Toll-like receptor 4-dependent cell activation at picomolar concentrations. Proc Natl Acad Sci U S A. 2004;101(12):4186-4191. 
10. Ohto U, Fukase K, Miyake K, Satow Y. Crystal structures of human MD-2 and its complex with antiendotoxic lipid IVa. Science. 2007;316(5831):1632-1634.

11. Loiarro M, Ruggiero V, Sette C. Targeting TLR/IL-1R signalling in human diseases. Mediators Inflamm. 2010;2010:674363.

12. Sato Y, Goto Y, Narita N, Hoon DS. Cancer Cells Expressing Toll-like Receptors and the Tumor Microenvironment. Cancer Microenviron. 2009;2 Suppl 1:205-214.

13. Pimentel-Nunes P, Soares JB, Roncon-Albuquerque R, Dinis-Ribeiro M, Leite-Moreira AF. Toll-like receptors as therapeutic targets in gastrointestinal diseases. Expert Opin Ther Targets. 2010;14(4):347-368.

14. Otte JM, Cario E, Podolsky DK. Mechanisms of cross hyporesponsiveness to Toll-like receptor bacterial ligands in intestinal epithelial cells. Gastroenterology. 2004;126(4):1054-1070.

15. Mansell A, Smith R, Doyle SL, et al. Suppressor of cytokine signaling 1 negatively regulates Toll-like receptor signaling by mediating Mal degradation. Nat Immunol. 2006;7(2):148-155.

16. Pimentel-Nunes P, Gonçalves N, Boal-Carvalho I, et al. Helicobacter pylori induces increased expression of Toll-like receptors and decreased Toll-interacting protein in gastric mucosa that persists throughout gastric carcinogenesis. Helicobacter. 2013;18(1):22-32.

17. Tsan MF. Toll-like receptors, inflammation and cancer. Semin Cancer Biol. 2006;16(1):32-37.

18. Kimbrell DA, Beutler B. The evolution and genetics of innate immunity. Nat Rev Genet. 2001;2(4):256-267.

19. Kawai T, Akira $S$. The role of pattern-recognition receptors in innate immunity: update on Toll-like receptors. Nat Immunol. 2010;11(5): 373-384.

20. Lu YC, Yeh WC, Ohashi PS. LPS/TLR4 signal transduction pathway. Cytokine. 2008;42(2):145-151.

21. Underhill DM. Toll-like receptors: networking for success. Eur $J$ Immunol. 2003;33(7):1767-1775.

22. So EY, Ouchi T. The application of Toll like receptors for cancer therapy. Int J Biol Sci. 2010;6(7):675-681.

23. French SW, Oliva J, French BA, Li J, Bardag-Gorce F. Alcohol, nutrition and liver cancer: role of Toll-like receptor signaling. World $J$ Gastroenterol. 2010;16(11):1344-1348.

24. Rakoff-Nahoum S, Medzhitov R. Toll-like receptors and cancer. Nat Rev Cancer. 2009;9(1):57-63.

25. Huang B, Zhao J, Unkeless JC, Feng ZH, Xiong H. TLR signaling by tumor and immune cells: a double-edged sword. Oncogene. 2008;27(2):218-224.

26. Miyake K. Roles for accessory molecules in microbial recognition by Toll-like receptors. J Endotoxin Res. 2006;12(4):195-204.

27. Miller SI, Ernst RK, Bader MW. LPS, TLR4 and infectious disease diversity. Nat Rev Microbiol. 2005;3(1):36-46.

28. Oblak A, Jerala R. Toll-like receptor 4 activation in cancer progression and therapy. Clin Dev Immunol. 2011;2011:609579.

29. Park SH, Kim ND, Jung JK, Lee CK, Han SB, Kim Y. Myeloid differentiation 2 as a therapeutic target of inflammatory disorders. Pharmacol Ther. 2012;133(3):291-298.

30. Akira S, Uematsu S, Takeuchi O. Pathogen recognition and innate immunity. Cell. 2006;124(4):783-801.

31. Fukata M, Abreu MT. Role of Toll-like receptors in gastrointestinal malignancies. Oncogene. 2008;27(2):234-243.

32. Goto Y, Arigami T, Kitago M, et al. Activation of Toll-like receptors 2, 3, and 4 on human melanoma cells induces inflammatory factors. Mol Cancer Ther. 2008;7(11):3642-3653.

33. He W, Liu Q, Wang L, Chen W, Li N, Cao X. TLR4 signaling promotes immune escape of human lung cancer cells by inducing immunosuppressive cytokines and apoptosis resistance. Mol Immunol. 2007;44(11): 2850-2859.

34. Kelly MG, Alvero AB, Chen R, et al. TLR-4 signaling promotes tumor growth and paclitaxel chemoresistance in ovarian cancer. Cancer Res. 2006;66(7):3859-3868.

35. Li H, Han Y, Guo Q, Zhang M, Cao X. Cancer-expanded myeloidderived suppressor cells induce anergy of NK cells through membranebound TGF-beta 1. J Immunol. 2009;182(1):240-249.
36. Strauss L, Bergmann C, Whiteside TL. Human circulating CD4+CD25highFoxp3+ regulatory $\mathrm{T}$ cells kill autologous CD8+ but not CD4+ responder cells by Fas-mediated apoptosis. $J$ Immunol. 2009;182(3):1469-1480.

37. Fukata M, Chen A, Vamadevan AS, et al. Toll-like receptor-4 promotes the development of colitis-associated colorectal tumors. Gastroenterology. 2007;133(6):1869-1881.

38. Uronis JM, Mühlbauer M, Herfarth HH, Rubinas TC, Jones GS, Jobin C. Modulation of the intestinal microbiota alters colitis-associated colorectal cancer susceptibility. PLoS One. 2009;4(6):e6026.

39. Swann JB, Vesely MD, Silva A, et al. Demonstration of inflammation-induced cancer and cancer immunoediting during primary tumorigenesis. Proc Natl Acad Sci U S A. 2008;105(2):652-656.

40. Naugler WE, Sakurai T, Kim S, et al. Gender disparity in liver cancer due to sex differences in MyD88-dependent IL-6 production. Science. 2007;317(5834):121-124.

41. Rakoff-Nahoum S, Medzhitov R. Regulation of spontaneous intestinal tumorigenesis through the adaptor protein MyD88. Science. 2007;317(5834):124-127.

42. Killeen SD, Wang JH, Andrews EJ, Redmond HP. Bacterial endotoxin enhances colorectal cancer cell adhesion and invasion through TLR-4 and NF-kappaB-dependent activation of the urokinase plasminogen activator system. Br J Cancer. 2009;100(10):1589-1602.

43. Huang B, Zhao J, Li H, et al. Toll-like receptors on tumor cells facilitate evasion of immune surveillance. Cancer Res. 2005;65(12): 5009-5014.

44. Dan HC, Sun M, Kaneko S, et al. Akt phosphorylation and stabilization of X-linked inhibitor of apoptosis protein (XIAP). J Biol Chem. 2004;279(7):5405-5412.

45. Akira S, Takeda K. Toll-like receptor signalling. Nat Rev Immunol. 2004;4(7):499-511.

46. Fukata M, Abreu MT. Pathogen recognition receptors, cancer and inflammation in the gut. Curr Opin Pharmacol. 2009;9(6):680-687.

47. Lotze MT, Zeh HJ, Rubartelli A, et al. The grateful dead: damageassociated molecular pattern molecules and reduction/oxidation regulate immunity. Immunol Rev. 2007;220:60-81.

48. Ellerman JE, Brown CK, de Vera M, et al. Masquerader: high mobility group box-1 and cancer. Clin Cancer Res. 2007;13(10):2836-2848.

49. Brezniceanu ML, Völp K, Bösser S, et al. HMGB1 inhibits cell death in yeast and mammalian cells and is abundantly expressed in human breast carcinoma. FASEB J. 2003;17(10):1295-1297.

50. Poser I, Golob M, Buettner R, Bosserhoff AK. Upregulation of HMG1 leads to melanoma inhibitory activity expression in malignant melanoma cells and contributes to their malignancy phenotype. Mol Cell Biol. 2003;23(8):2991-2998.

51. Sasahira T, Kirita T, Oue N, et al. High mobility group box-1-inducible melanoma inhibitory activity is associated with nodal metastasis and lymphangiogenesis in oral squamous cell carcinoma. Cancer Sci. 2008;99(9):1806-1812.

52. Schlueter C, Weber H, Meyer B, et al. Angiogenetic signaling through hypoxia: HMGB1: an angiogenetic switch molecule. Am J Pathol. 2005;166(4):1259-1263.

53. van Beijnum JR, Petersen K, Griffioen AW. Tumor endothelium is characterized by a matrix remodeling signature. Front Biosci (Schol Ed). 2009;1:216-225.

54. Sims GP, Rowe DC, Rietdijk ST, Herbst R, Coyle AJ. HMGB1 and RAGE in inflammation and cancer. Annu Rev Immunol. 2010;28:367-388.

55. Hiratsuka S, Ishibashi S, Tomita T, et al. Primary tumours modulate innate immune signalling to create pre-metastatic vascular hyperpermeability foci. Nat Commun. 2013;4:1853.

56. Hiratsuka S, Watanabe A, Sakurai Y, et al. The S100A8-serum amyloid A3-TLR4 paracrine cascade establishes a pre-metastatic phase. Nat Cell Biol. 2008;10(11):1349-1355.

57. Mantovani A, Allavena P, Sica A, Balkwill F. Cancer-related inflammation. Nature. 2008;454(7203):436-444.

58. Candido J, Hagemann T. Cancer-related inflammation. J Clin Immunol. 2013;33 Suppl 1:S79-S84. 
59. Perrone G, Ruffini PA, Catalano V, et al. Intratumoural FOXP3-positive regulatory $\mathrm{T}$ cells are associated with adverse prognosis in radically resected gastric cancer. Eur J Cancer. 2008;44(13):1875-1882.

60. Martinez FO, Sica A, Mantovani A, Locati M. Macrophage activation and polarization. Front Biosci. 2008;13:453-461.

61. Zou W. Immunosuppressive networks in the tumour environment and their therapeutic relevance. Nat Rev Cancer. 2005;5(4):263-274.

62. Zhou YH, Liao SJ, Li D, et al. TLR4 ligand $/ \mathrm{H}_{2} \mathrm{O}_{2}$ enhances TGF- $\beta 1$ signaling to induce metastatic potential of non-invasive breast cancer cells by activating non-Smad pathways. PLoS One. 2013;8(5):e65906.

63. Seki E, De Minicis S, Osterreicher CH, et al. TLR4 enhances TGF-beta signaling and hepatic fibrosis. Nat Med. 2007;13(11):1324-1332.

64. Bhowmick NA, Chytil A, Plieth D, et al. TGF-beta signaling in fibroblasts modulates the oncogenic potential of adjacent epithelia. Science. 2004;303(5659):848-851.

65. Azuma I, Seya T. Development of immunoadjuvants for immunotherapy of cancer. Int Immunopharmacol. 2001;1(7):1249-1259.

66. Okamoto M, Furuichi S, Nishioka Y, et al. Expression of toll-like receptor 4 on dendritic cells is significant for anticancer effect of dendritic cell-based immunotherapy in combination with an active component of OK-432, a streptococcal preparation. Cancer Res. 2004;64(15):5461-5470.

67. Okamoto M, Sato M. Toll-like receptor signaling in anti-cancer immunity. J Med Invest. 2003;50(1-2):9-24.

68. Lin YS, Huang LD, Lin CH, et al. In vitro and in vivo anticancer activity of a synthetic glycolipid as Toll-like receptor 4 (TLR4) activator. J Biol Chem. 2011;286(51):43782-43792.

69. Grondin V, Seksik P, Dumont S, et al. Regulation of colon cancer cell proliferation and migration by MD-2 activity. Innate Immun. 2011;17(4):414-422.

70. Deguchi A, Tomita T, Omori T, et al. Serum Amyloid A3 Binds MD-2 To Activate p38 and NF- $\mathrm{kB}$ Pathways in a MyD88-Dependent Manner. J Immunol. 2013;191(4):1856-1864.

71. Hartmann E, Wollenberg B, Rothenfusser S, et al. Identification and functional analysis of tumor-infiltrating plasmacytoid dendritic cells in head and neck cancer. Cancer Res. 2003;63(19):6478-6487.

72. Szczepański M, Stelmachowska M, Stryczyński L, et al. Assessment of expression of toll-like receptors 2, 3 and 4 in laryngeal carcinoma. Eur Arch Otorhinolaryngol. 2007;264(5):525-530.

73. Szczepanski MJ, Czystowska M, Szajnik M, et al. Triggering of Tolllike receptor 4 expressed on human head and neck squamous cell carcinoma promotes tumor development and protects the tumor from immune attack. Cancer Res. 2009;69(7):3105-3113.

74. Starska K, Forma E, Lewy-Trenda I, et al. The expression of SOCS1 and TLR4-NFkappaB pathway molecules in neoplastic cells as potential biomarker for the aggressive tumor phenotype in laryngeal carcinoma. Folia Histochem Cytobiol. 2009;47(3):401-410.

75. Starska K, Forma E, Bryś M, et al. The expression of TLR pathway molecules in peripheral blood mononuclear cells and their relationship with tumor invasion and cytokine secretion in laryngeal carcinoma. Adv Med Sci. 2012;57(1):124-135.

76. Yao H, Rahman I. Current concepts on the role of inflammation in COPD and lung cancer. Curr Opin Pharmacol. 2009;9(4):375-383

77. Bauer AK, Dixon D, DeGraff LM, et al. Toll-like receptor 4 in butylated hydroxytoluene-induced mouse pulmonary inflammation and tumorigenesis. J Natl Cancer Inst. 2005;97(23):1778-1781.

78. Bauer AK, Fostel J, Degraff LM, et al. Transcriptomic analysis of pathways regulated by toll-like receptor 4 in a murine model of chronic pulmonary inflammation and carcinogenesis. Mol Cancer. 2009;8:107.

79. MacRedmond RE, Greene CM, Dorscheid DR, McElvaney NG, O'Neill SJ. Epithelial expression of TLR4 is modulated in COPD and by steroids, salmeterol and cigarette smoke. Respir Res. 2007; $8: 84$.

80. Zhang YB, He FL, Fang M, et al. Increased expression of Toll-like receptors 4 and 9 in human lung cancer. Mol Biol Rep. 2009;36(6): $1475-1481$.
81. Manegold C, Gravenor D, Woytowitz D, et al. Randomized phase II trial of a toll-like receptor 9 agonist oligodeoxynucleotide, PF-3512676, in combination with first-line taxane plus platinum chemotherapy for advanced-stage non-small-cell lung cancer. J Clin Oncol. 2008;26(24):3979-3986.

82. Ren T, Wen ZK, Liu ZM, et al. Targeting toll-like receptor 9 with CpG oligodeoxynucleotides enhances anti-tumor responses of peripheral blood mononuclear cells from human lung cancer patients. Cancer Invest. 2008;26(5):448-455.

83. Wang H, Rayburn ER, Wang W, Kandimalla ER, Agrawal S, Zhang R. Chemotherapy and chemosensitization of non-small cell lung cancer with a novel immunomodulatory oligonucleotide targeting Toll-like receptor 9. Mol Cancer Ther. 2006;5(6):1585-1592.

84. Droemann D, Albrecht D, Gerdes J, et al. Human lung cancer cells express functionally active Toll-like receptor 9. Respir Res. 2005;6:1.

85. Parkin DM, Pisani P, Ferlay J. Global cancer statistics. CA Cancer J Clin. 1999;49(1):33-64, 1.

86. McCulloch P, Ward J, Tekkis PP; ASCOT group of surgeons; British Oesophago-Gastric Cancer Group. Mortality and morbidity in gastro-oesophageal cancer surgery: initial results of ASCOT multicentre prospective cohort study. BMJ. 2003;327(7425): 1192-1197.

87. Chattopadhyay I, Singh A, Phukan R, et al. Genome-wide analysis of chromosomal alterations in patients with esophageal squamous cell carcinoma exposed to tobacco and betel quid from high-risk area in India. Mutat Res. 2010;696(2):130-138.

88. Sheyhidin I, Nabi G, Hasim A, et al. Overexpression of TLR3, TLR4, TLR7 and TLR9 in esophageal squamous cell carcinoma. World $J$ Gastroenterol. 2011;17(32):3745-3751.

89. Kawahara T, Kuwano Y, Teshima-Kondo S, et al. Toll-like receptor 4 regulates gastric pit cell responses to Helicobacter pylori infection. J Med Invest. 2001;48(3-4):190-197.

90. Ishihara S, Rumi MA, Kadowaki Y, et al. Essential role of MD-2 in TLR4-dependent signaling during Helicobacter pylori-associated gastritis. J Immunol. 2004;173(2):1406-1416.

91. Chochi K, Ichikura T, Kinoshita M, et al. Helicobacter pylori augments growth of gastric cancers via the lipopolysaccharide-toll-like receptor 4 pathway whereas its lipopolysaccharide attenuates antitumor activities of human mononuclear cells. Clin Cancer Res. 2008;14(10): 2909-2917.

92. Schmausser B, Andrulis M, Endrich S, Müller-Hermelink HK, Eck M. Toll-like receptors TLR4, TLR5 and TLR9 on gastric carcinoma cells: an implication for interaction with Helicobacter pylori. Int $\mathrm{J} \mathrm{Med}$ Microbiol. 2005;295(3):179-185.

93. Kawauchi K, Yagihashi A, Tsuji N, et al. Human beta-defensin-3 induction in $\mathrm{H}$. pylori-infected gastric mucosal tissues. World $J$ Gastroenterol. 2006;12(36):5793-5797.

94. Fukata M, Chen A, Klepper A, et al. Cox-2 is regulated by Toll-like receptor-4 (TLR4) signaling: role in proliferation and apoptosis in the intestine. Gastroenterology. 2006;131(3):862-877.

95. Ohara T, Morishita T, Suzuki H, Hibi T. Heterozygous Thr 135 Ala polymorphism at leucine-rich repeat (LRR) in genomic DNA of toll-like receptor 4 in patients with poorly-differentiated gastric adenocarcinomas. Int J Mol Med. 2006;18(1):59-63.

96. Hold GL, Rabkin CS, Chow WH, et al. A functional polymorphism of toll-like receptor 4 gene increases risk of gastric carcinoma and its precursors. Gastroenterology. 2007;132(3):905-912.

97. Santini D, Angeletti S, Ruzzo A, et al. Toll-like receptor 4 Asp299Gly and Thr399Ile polymorphisms in gastric cancer of intestinal and diffuse histotypes. Clin Exp Immunol. 2008;154(3):360-364.

98. Trejo-de la O A, Torres J, Pérez-Rodríguez M, et al. TLR4 single-nucleotide polymorphisms alter mucosal cytokine and chemokine patterns in Mexican patients with Helicobacter pylori-associated gastroduodenal diseases. Clin Immunol. 2008;129(2):333-340.

99. Rigoli L, Di Bella C, Fedele F, et al. TLR4 and NOD2/CARD15 genetic polymorphisms and their possible role in gastric carcinogenesis. Anticancer Res. 2010;30(2):513-517. 
100. Garza-Gonzalez E, Bosques-Padilla FJ, Mendoza-Ibarra SI, FloresGutierrez JP, Maldonado-Garza HJ, Perez-Perez GI. Assessment of the toll-like receptor 4 Asp299Gly, Thr399Ile and interleukin-8 -251 polymorphisms in the risk for the development of distal gastric cancer. BMC Cancer. 2007;7:70.

101. Fukata M, Abreu MT. TLR4 signalling in the intestine in health and disease. Biochem Soc Trans. 2007;35(Pt 6):1473-1478.

102. Cario E, Podolsky DK. Differential alteration in intestinal epithelial cell expression of toll-like receptor 3 (TLR3) and TLR4 in inflammatory bowel disease. Infect Immun. 2000;68(12):7010-7017.

103. Abreu MT, Fukata M, Arditi M. TLR signaling in the gut in health and disease. J Immunol. 2005;174(8):4453-4460.

104. Hausmann M, Kiessling S, Mestermann S, et al. Toll-like receptors 2 and 4 are up-regulated during intestinal inflammation. Gastroenterology. 2002;122(7):1987-2000.

105. Cammarota R, Bertolini V, Pennesi G, et al. The tumor microenvironment of colorectal cancer: stromal TLR-4 expression as a potential prognostic marker. J Transl Med. 2010;8:112.

106. Furrie E, Macfarlane S, Thomson G, Macfarlane GT; Microbiology and Gut Biology Group; Tayside Tissue and Tumour Bank. Toll-like receptors-2, -3 and -4 expression patterns on human colon and their regulation by mucosal-associated bacteria. Immunology. 2005;115(4): 565-574.

107. Rigoli L, Romano C, Caruso RA, et al. Clinical significance of NOD2/CARD15 and Toll-like receptor 4 gene single nucleotide polymorphisms in inflammatory bowel disease. World J Gastroenterol. 2008;14(28):4454-4461.

108. Hong J, Leung E, Fraser AG, Merriman TR, Vishnu P, Krissansen GW. TLR2, TLR4 and TLR9 polymorphisms and Crohn's disease in a New Zealand Caucasian cohort. J Gastroenterol Hepatol. 2007;22(11): $1760-1766$.

109. Baumgart DC, Buning C, Geerdts L, et al. The c. $1-260 \mathrm{C}>\mathrm{T}$ promoter variant of CD14 but not the c.896A $>$ G (p.D299G) variant of tolllike receptor 4 (TLR4) genes is associated with inflammatory bowel disease. Digestion. 2007;76(3-4):196-202.

110. Franchimont D, Vermeire S, El Housni H, et al. Deficient host-bacteria interactions in inflammatory bowel disease? The toll-like receptor (TLR)-4 Asp299 gly polymorphism is associated with Crohn's disease and ulcerative colitis. Gut. 2004;53(7):987-992.

111. Brand S, Staudinger T, Schnitzler F, et al. The role of Toll-like receptor 4 Asp299Gly and Thr399Ile polymorphisms and CARD15/ NOD2 mutations in the susceptibility and phenotype of Crohn's disease. Inflamm Bowel Dis. 2005;11(7):645-652.

112. Gazouli M, Mantzaris G, Kotsinas A, et al. Association between polymorphisms in the Toll-like receptor 4, CD14, and CARD15/NOD2 and inflammatory bowel disease in the Greek population. World $J$ Gastroenterol. 2005;11(5):681-685.

113. Török HP, Glas J, Tonenchi L, Mussack T, Folwaczny C. Polymorphisms of the lipopolysaccharide-signaling complex in inflammatory bowel disease: association of a mutation in the Toll-like receptor 4 gene with ulcerative colitis. Clin Immunol. 2004;112(1): 85-91.

114. Oostenbrug LE, Drenth JP, de Jong DJ, et al. Association between Toll-like receptor 4 and inflammatory bowel disease. Inflamm Bowel Dis. 2005;11(6):567-575.

115. Ouburg S, Mallant-Hent R, Crusius JB, et al. The toll-like receptor 4 (TLR4) Asp299Gly polymorphism is associated with colonic localisation of Crohn's disease without a major role for the Saccharomyces cerevisiae mannan-LBP-CD14-TLR4 pathway. Gut. 2005;54(3):439-440.

116. Shen X, Shi R, Zhang H, Li K, Zhao Y, Zhang R. The Toll-like receptor 4 D299G and T399I polymorphisms are associated with Crohn's disease and ulcerative colitis: a meta-analysis. Digestion. 2010;81(2): 69-77.

117. Boraska Jelavić T, Barisić M, Drmic Hofman I, et al. Microsatelite GT polymorphism in the toll-like receptor 2 is associated with colorectal cancer. Clin Genet. 2006;70(2):156-160.
118. Wang JH, Manning BJ, Wu QD, Blankson S, Bouchier-Hayes D, Redmond HP. Endotoxin/lipopolysaccharide activates NF-kappa B and enhances tumor cell adhesion and invasion through a beta 1 integrindependent mechanism. J Immunol. 2003;170(2):795-804.

119. Andrews EJ, Wang JH, Winter DC, Laug WE, Redmond HP. Tumor cell adhesion to endothelial cells is increased by endotoxin via an upregulation of beta-1 integrin expression. J Surg Res. 2001;97(1): 14-19.

120. Hsu RY, Chan CH, Spicer JD, et al. LPS-induced TLR4 signaling in human colorectal cancer cells increases beta1 integrin-mediated cell adhesion and liver metastasis. Cancer Res. 2011;71(5):1989-1998.

121. Friedman SL. Molecular regulation of hepatic fibrosis, an integrated cellular response to tissue injury. J Biol Chem. 2000;275(4): 2247-2250.

122. Testro AG, Visvanathan $\mathrm{K}$. Toll-like receptors and their role in gastrointestinal disease. J Gastroenterol Hepatol. 2009;24(6): 943-954.

123. Wang JP, Zhang Y, Wei X, et al. Circulating Toll-like receptor (TLR) 2, TLR4, and regulatory T cells in patients with chronic hepatitis C. APMIS. 2010;118(4):261-270.

124. Wei XQ, Guo YW, Liu JJ, Wen ZF, Yang SJ, Yao JL. The significance of Toll-like receptor 4 (TLR4) expression in patients with chronic hepatitis B. Clin Invest Med. 2008;31(3):E123-E130.

125. Machida K, Tsukamoto H, Mkrtchyan H, et al. Toll-like receptor 4 mediates synergism between alcohol and HCV in hepatic oncogenesis involving stem cell marker Nanog. Proc Natl Acad Sci USA. 2009;106(5):1548-1553.

126. Nishimura M, Naito $\mathrm{S}$. Tissue-specific mRNA expression profiles of human toll-like receptors and related genes. Biol Pharm Bull. 2005;28(5):886-892.

127. Vonlaufen A, Xu Z, Daniel B, et al. Bacterial endotoxin: a trigger factor for alcoholic pancreatitis? Evidence from a novel, physiologically relevant animal model. Gastroenterology. 2007;133(4):1293-1303.

128. Zhang JJ, Wu HS, Wang L, Tian Y, Zhang JH, Wu HL. Expression and significance of TLR4 and HIF-1alpha in pancreatic ductal adenocarcinoma. World J Gastroenterol. 2010;16(23):2881-2888.

129. Miller LS. Toll-like receptors in skin. Adv Dermatol. 2008;24: 71-87.

130. Molteni M, Marabella D, Orlandi C, Rossetti C. Melanoma cell lines are responsive in vitro to lipopolysaccharide and express TLR-4. Cancer Lett. 2006;235(1):75-83.

131. Sanchez-Perez L, Kottke T, Daniels GA, et al. Killing of normal melanocytes, combined with heat shock protein 70 and CD40L expression, cures large established melanomas. J Immunol. 2006;177(6): $4168-4177$.

132. Voelcker V, Gebhardt C, Averbeck M, et al. Hyaluronan fragments induce cytokine and metalloprotease upregulation in human melanoma cells in part by signalling via TLR4. Exp Dermatol. 2008;17(2): 100-107.

133. Saint-Jean M, Knol AC, Nguyen JM, Khammari A, Dréno B. TLR expression in human melanoma cells. Eur J Dermatol. 2011;21(6): 899-905.

134. Wu J, Guan M, Wong PF, Yu H, Dong J, Xu J. Icariside II potentiates paclitaxel-induced apoptosis in human melanoma A375 cells by inhibiting TLR4 signaling pathway. Food Chem Toxicol. 2012;50(9): 3019-3024.

135. Yusuf N, Nasti TH, Long JA, et al. Protective role of Toll-like receptor 4 during the initiation stage of cutaneous chemical carcinogenesis. Cancer Res. 2008;68(2):615-622.

136. Clarke JH, Cha JY, Walsh MD, et al. Melanoma inhibits macrophage activation by suppressing toll-like receptor 4 signaling. J Am Coll Surg. 2005;201(3):418-425.

137. Xie W, Wang Y, Huang Y, Yang H, Wang J, Hu Z. Toll-like receptor 2 mediates invasion via activating NF-kappaB in MDA-MB-231 breast cancer cells. Biochem Biophys Res Commun. 2009;379(4): 1027-1032. 
138. Merrell MA, Ilvesaro JM, Lehtonen N, et al. Toll-like receptor 9 agonists promote cellular invasion by increasing matrix metalloproteinase activity. Mol Cancer Res. 2006;4(7):437-447.

139. Yang H, Zhou H, Feng P, et al. Reduced expression of Toll-like receptor 4 inhibits human breast cancer cells proliferation and inflammatory cytokines secretion. J Exp Clin Cancer Res. 2010;29:92.

140. Harmey JH, Bucana CD, Lu W, et al. Lipopolysaccharide-induced metastatic growth is associated with increased angiogenesis, vascular permeability and tumor cell invasion. Int J Cancer. 2002;101(5): 415-422.

141. Ahmed A, Wang JH, Redmond HP. Silencing of TLR4 increases tumor progression and lung metastasis in a murine model of breast cancer. Ann Surg Oncol. Epub 2012 Aug 14.

142. Ehsan N, Murad S, Ashiq T, et al. Significant correlation of TLR4 expression with the clinicopathological features of invasive ductal carcinoma of the breast. Tumour Biol. 2013;34(2):1053-1059.

143. González-Reyes S, Marín L, González L, et al. Study of TLR3, TLR4 and TLR9 in breast carcinomas and their association with metastasis. BMC Cancer. 2010;10:665.

144. Liao SJ, Zhou YH, Yuan Y, et al. Triggering of Toll-like receptor 4 on metastatic breast cancer cells promotes $\alpha v \beta 3$-mediated adhesion and invasive migration. Breast Cancer Res Treat. 2012;133(3):853-863.

145. Apetoh L, Tesniere A, Ghiringhelli F, Kroemer G, Zitvogel L. Molecular interactions between dying tumor cells and the innate immune system determine the efficacy of conventional anticancer therapies. Cancer Res. 2008;68(11):4026-4030.

146. Theodoropoulos GE, Saridakis V, Karantanos T, et al. Toll-like receptors gene polymorphisms may confer increased susceptibility to breast cancer development. Breast. 2012;21(4):534-538.

147. Etokebe GE, Knezević J, Petricević B, Pavelić J, Vrbanec D, Dembić Z. Single-nucleotide polymorphisms in genes encoding toll-like receptor $-2,-3,-4$, and -9 in case-control study with breast cancer. Genet Test Mol Biomarkers. 2009;13(6):729-734.

148. Szajnik M, Szczepanski MJ, Czystowska M, et al. TLR4 signaling induced by lipopolysaccharide or paclitaxel regulates tumor survival and chemoresistance in ovarian cancer. Oncogene. 2009;28(49): 4353-4363.

149. Klink M, Nowak M, Kielbik M, et al. The interaction of HspA1A with TLR2 and TLR4 in the response of neutrophils induced by ovarian cancer cells in vitro. Cell Stress Chaperones. 2012;17(6):661-674.

150. Wang AC, Su QB, Wu FX, Zhang XL, Liu PS. Role of TLR4 for paclitaxel chemotherapy in human epithelial ovarian cancer cells. Eur J Clin Invest. 2009;39(2):157-164.

151. Stanley MA, Pett MR, Coleman N. HPV: from infection to cancer. Biochem Soc Trans. 2007;35(Pt 6):1456-1460.

152. Platz-Christensen JJ, Sundström E, Larsson PG. Bacterial vaginosis and cervical intraepithelial neoplasia. Acta Obstet Gynecol Scand. 1994;73(7):586-588.

153. Smith JS, Bosetti C, Muñoz N, et al; IARC multicentric case-control study. Chlamydia trachomatis and invasive cervical cancer: a pooled analysis of the IARC multicentric case-control study. Int J Cancer. 2004;111(3):431-439.

154. Werner J, Decarlo CA, Escott N, Zehbe I, Ulanova M. Expression of integrins and Toll-like receptors in cervical cancer: effect of infectious agents. Innate Immun. 2012;18(1):55-69.
155. Yu L, Wang L, Li M, Zhong J, Wang Z, Chen S. Expression of toll-like receptor 4 is down-regulated during progression of cervical neoplasia. Cancer Immunol Immunother. 2010;59(7):1021-1028.

156. Hasan UA, Bates E, Takeshita F, et al. TLR9 expression and function is abolished by the cervical cancer-associated human papillomavirus type 16. J Immunol. 2007;178(5):3186-3197.

157. Pandey S, Mittal RD, Srivastava M, et al. Impact of Toll-like receptors [TLR] 2 (-196 to $-174 \mathrm{del}$ ) and TLR 4 (Asp299Gly, Thr399Ile) in cervical cancer susceptibility in North Indian women. Gynecol Oncol. 2009;114(3):501-505.

158. Gatti G, Rivero V, Motrich RD, Maccioni M. Prostate epithelial cells can act as early sensors of infection by up-regulating TLR4 expression and proinflammatory mediators upon LPS stimulation. J Leukoc Biol. 2006;79(5):989-998

159. González-Reyes S, Fernández JM, González LO, et al. Study of TLR3, TLR4, and TLR9 in prostate carcinomas and their association with biochemical recurrence. Cancer Immunol Immunother. 2011;60(2): 217-226.

160. Gatti G, Quintar AA, Andreani V, et al. Expression of Toll-like receptor 4 in the prostate gland and its association with the severity of prostate cancer. Prostate. 2009;69(13):1387-1397.

161. Pei Z, Lin D, Song X, Li H, Yao H. TLR4 signaling promotes the expression of VEGF and TGFbetal in human prostate epithelial PC3 cells induced by lipopolysaccharide. Cell Immunol. 2008;254(1) 20-27.

162. Hua D, Liu MY, Cheng ZD, et al. Small interfering RNAdirected targeting of Toll-like receptor 4 inhibits human prostate cancer cell invasion, survival, and tumorigenicity. Mol Immunol. 2009;46(15):2876-2884.

163. Vidas Z. Polymorphisms in Toll-like receptor genes - implications for prostate cancer development. Coll Antropol. 2010;34(2):779-783.

164. Zheng SL, Augustsson-Bälter K, Chang B, et al. Sequence variants of toll-like receptor 4 are associated with prostate cancer risk: results from the CAncer Prostate in Sweden Study. Cancer Res. 2004;64(8): 2918-2922.

165. Song J, Kim DY, Kim CS, et al. The association between Toll-like receptor 4 (TLR4) polymorphisms and the risk of prostate cancer in Korean men. Cancer Genet Cytogenet. 2009;190(2):88-92.

166. Chen YC, Giovannucci E, Lazarus R, Kraft P, Ketkar S, Hunter DJ. Sequence variants of Toll-like receptor 4 and susceptibility to prostate cancer. Cancer Res. 2005;65(24):11771-11778.

167. Cheng I, Plummer SJ, Casey G, Witte JS. Toll-like receptor 4 genetic variation and advanced prostate cancer risk. Cancer Epidemiol Biomarkers Prev. 2007;16(2):352-355.

168. Lindström S, Hunter DJ, Grönberg H, et al. Sequence variants in the TLR4 and TLR6-1-10 genes and prostate cancer risk. Results based on pooled analysis from three independent studies. Cancer Epidemiol Biomarkers Prev. 2010;19(3):873-876.
OncoTargets and Therapy

\section{Publish your work in this journal}

OncoTargets and Therapy is an international, peer-reviewed, open access journal focusing on the pathological basis of all cancers, potential targets for therapy and treatment protocols employed to improve the management of cancer patients. The journal also focuses on the impact of management programs and new therapeutic agents and protocols on

\section{Dovepress}

patient perspectives such as quality of life, adherence and satisfaction The manuscript management system is completely online and includes a very quick and fair peer-review system, which is all easy to use. Visit http://www.dovepress.com/testimonials.php to read real quotes from published authors. 